\title{
MEASURING TOURISM EXPERIENCE: PERSPECTIVES OF DIFFERENT TOURISTS SEGMENTS
}

\author{
Suzana Marković ${ }^{1}$ \\ Sanja Raspor Janković ${ }^{2}$ \\ Irena $\breve{S k e r}^{3}$
}

Received: June 25, 2021 / Revised: October 5, 2021 / Accepted: October 27, 2021

(C) Association of Economists and Managers of the Balkans, 2021

\begin{abstract}
The present study explores tourism experience construct and its outcomes at a local heritage site in Croatia. It aims to investigate potential differences in heritage tourism experience in regard to visitors' nationality and frequency of visiting the site. The tourism experience construct was measured with five dimensions (senses, on-site engagement, staff, learning, emotions), while three constructs were deemed as tourism experience outcomes (satisfaction, behavioral intentions, and memory). A sample of 165 respondents was collected from heritage site visitors. Descriptive statistics and t-test were performed to analyze data and to address the research questions. The results revealed that domestic visitors and the repeated ones reported significantly more positive heritage site experience, and expressed significantly higher levels of experience outcomes than foreign and first-time visitors.
\end{abstract}

Keywords: Tourism experience dimensions, Tourism experience outcomes, Measurement, Heritage site, Visitors' nationality and the number of visits.

\section{JEL Classification L83}

suzanam@fthm.hr

University of Rijeka, Faculty of Tourism and Hospitality Management, Primorska 46, 51410 Opatija, Croatia Polytechnic of Rijeka, Trpimirova 2/V, 51000 Rijeka, Croatia

University of Rijeka, Faculty of Tourism and Hospitality Management Opatija, Primorska 42, P.O. Box 97, 51410 Opatija, Croatia 


\section{INTRODUCTION}

Tourists are not merely passive participants in destination experience but can be active seekers of knowledge, engagement, entertainment, recreation, and leisure. According to Joyner et al. (2018), tourists seek experiences where they can be involved with and learn. Moreover, Schmitt (1999) argues that experiences are personal, a response to stimulation, and frequently are a consequence of direct participation in the real or virtual event.

The visitor experience is increasingly recognized as a core product of heritage site offerings (Packer \& Ballantyne, 2016). In this context, heritage interpretation aims to educate, entertain and immerse visitors in the physical environment, to consequently enhance their experience.

This paper focuses on measuring tourism experience construct, by exploring its dimensions and outcomes in the heritage tourism context. In particular, the study investigates potential differences between domestic and foreign visitors, as well as between first-time and repeated visitors regarding their tourism experience at a local heritage site in Croatia. In this context, a domestic visitor is defined as the one who stated Croatia as country of residence, while a foreign visitor is not a Croatian resident. Accordingly, a first-time visitor is a person that visited the site for the first time, while a repeated one has already visited the site on a previous occasion.

Therefore, the following research questions were proposed: (a) what are the key tourism experience dimensions and outcomes, (b) how visitors experience local heritage sites, (c) are there significant differences in visitors' experience regarding their nationality and frequency of visiting the site?

Previous research that addressed the role of nationality (e.g. country of residence) and frequency of visiting tourist destinations has found significant differences in visitors' behavior and their perceptions of the destination (Sayan \& Karagüzel, 2010; McKercher et al., 2011; Prayag \& Ryan, 2011). Thus, in the context of the present study, the assumption is that nationality and number of visits influence visitors' experience in heritage tourism.

The paper is structured as follows. In the conceptual framework, a brief review of tourism experience dimensions and outcomes is provided. In the methodology section, research instrument, data collection, and statistical analysis methods are described. This is followed by a study results presentation. The paper concludes with main research findings, limitations, and future research suggestions.

\section{CONCEPTUAL FRAMEWORK}

Tourists' experiences can be defined as subjective and personal responses to external and staged activities, settings, or events (Packer \& Ballantyne, 2016). In addition, experiences are enjoyable, engaging, memorable encounters for those consuming the events (Oh et al., 2007).

According to Chen \& Rahman (2018), tourism experience components and dimensions vary widely in research. Pine \& Gilmore (1998) identified four dimensions of customer experiences, namely entertainment, education, aesthetics, and escapism. Agapito et al. (2013) pinpointed the importance of visual and non-visual senses as dimensions of tourism experience. Godovykh \& Tasci (2020) concluded that the most frequently explained experience components are affective, cognitive, conative, and sensorial. 
Furthermore, in the context of cultural and heritage tourism research, several specific tourism experience dimensions were identified. Und \& Vong (2010) identified five heritage tourism experience dimensions, namely, history and culture, facilities and service at heritage sites, heritage interpretation, and heritage attractiveness. Kempiak et al. (2017) emphasized the role and importance of audio and visual communication, atmospherics, on-site engagement, information, and heritage preservation. Seyfi et al. (2019) found out that a memorable cultural tourism experience can be defined with the following six key factors: prior perceived significance of the experience, authenticity, engagement, cultural exchange, culinary attraction, and quality of service.

In addition, tourism experience can lead to different outcomes. Ali et al. (2014) found that customer service experience had a positive and significant impact on customer memories and loyalty intentions in resort hotels. Kempiak et al. (2017) proposed satisfaction and likelihood of revisit as post-visit experience factors in heritage attractions. Suhartanto et al. (2020) reported that tourist experience dimensions were significant predictors of tourist satisfaction and loyalty in agritourism settings.

\section{METHODOLOGY}

A questionnaire for collecting primary data was developed based on an extensive literature review and is divided into three parts that measure tourism experience construct, tourism experience outcomes, and respondents' demographic data.

The tourism experience construct was measured with 29 variables, combined in five dimensions, namely, senses, on-site engagement, staff, learning, and emotions. Variables for measuring tourism experience were adopted from Oh et al. (2007), Chandralal \& Valenzuela (2012), Anil (2012), Kim \& Perdue (2013), Marković et al. (2015), Kempiak et al. (2017), and Chua et al. (2019). Variables were measured with a 5-point Likert scale, ranging from "strongly disagree" as 1, to "strongly agree" as 5.

Moreover, variables for measuring three tourism experience outcomes were included in the questionnaire, as well. Firstly, satisfaction was measured with four items, adopted from Dagger et al. (2007). Next, behavioral intentions were measured with four items, adopted from Zeithaml, Berry \& Parasuraman (1996). Three items for measuring memory were adopted from Oh, Fiore \& Jeoung (2007). All variables were measured with a 5-point Likert scale, ranging from "strongly disagree" as 1 , to "strongly agree" as 5 .

Finally, respondents' demographic data included gender, age, country of residence, marital status, employment status, level of education, and personal income, motivation for visiting the site, number of visits to the site, number of people in the group, and number of accompanying children.

Questionnaires were administered to visitors of a medieval stone castle in the central part of Istria County in Croatia during summer 2020. Questionnaires were presented to potential respondents who were willing to participate in the survey. Completed questionnaires were collected from respondents on site.

Data analysis was performed on the sample of 165 valid questionnaires and included descriptive and bivariate statistical analyses. The respondents' demographics, as well as tourism experience elements, and tourism experience outcomes were evaluated with descriptive statistics methods, calculating percentages, mean, and standard deviation. The significance of differences in all examined constructs considering respondents' nationality and frequency of visiting the site, were tested with independent samples t-test. 


\section{STUDY RESULTS}

Sample's demographic and visit-related characteristics were as follows. There were more females (55.8 percent) than males (44.2 percent). Respondents' mean age was 40 years, and a majority of them were domestic visitors (62.4 percent). Over one-third of respondents ( 35.2 percent) had a secondary school degree. Similarly, 35.8 percent of respondents received a university education. About 70 percent of respondents were married and employed, with middle (40.0 percent) and upper-middle (38.6 percent) personal income. Moreover, the sample consisted of 66 percent of first-time visitors, that visited the site in a group of two or more people (63.1 percent), mostly with children (62.0 percent). Those who indicated cultural heritage as the main motive for visiting the site made up about 58 percent of the sample.

Table 1 reports the results of descriptive and bivariate statistical analyses for tourism experience scores.

Table 1. The comparison of tourism experience scores

\begin{tabular}{|c|c|c|c|c|c|c|}
\hline \multirow{2}{*}{ Variables } & \multicolumn{3}{|c|}{ Tourist origin } & \multicolumn{3}{|c|}{ Number of visits } \\
\hline & Domestic & Foreign & T-value & First time & Repeated & $\begin{array}{l}\text { T-value } \\
\end{array}$ \\
\hline Senses & 4.64 & 4.47 & & 4.52 & 4.67 & \\
\hline Rich cultural heritage & $\begin{array}{c}4.69 \\
(0.543) \\
\end{array}$ & $\begin{array}{c}4.53 \\
(0.535) \\
\end{array}$ & 1.810 & $\begin{array}{c}4.59 \\
(0.565) \\
\end{array}$ & $\begin{array}{c}4.71 \\
(0.494) \\
\end{array}$ & -1.490 \\
\hline Visual appearance & $\begin{array}{c}4.83 \\
(0.430)\end{array}$ & $\begin{array}{c}4.73 \\
(0.518)\end{array}$ & 1.272 & $\begin{array}{c}4.78 \\
(0.459)\end{array}$ & $\begin{array}{c}4.80 \\
(0.483)\end{array}$ & -0.309 \\
\hline Interior/exterior lighting effect & $\begin{array}{c}4.62 \\
(0.688) \\
\end{array}$ & $\begin{array}{c}4.60 \\
(0.610)\end{array}$ & 0.015 & $\begin{array}{c}4.57 \\
(0.713)\end{array}$ & $\begin{array}{c}4.71 \\
(0.530)\end{array}$ & -1.422 \\
\hline Interior/exterior color & $\begin{array}{c}4.70 \\
(0.624) \\
\end{array}$ & $\begin{array}{c}4.59 \\
(0.642) \\
\end{array}$ & 1.069 & $\begin{array}{c}4.60 \\
(0.696) \\
\end{array}$ & $\begin{array}{c}4.77 \\
(0.467) \\
\end{array}$ & -1.813 \\
\hline Unique interior & $\begin{array}{c}4.49 \\
(0.752) \\
\end{array}$ & $\begin{array}{c}4.10 \\
(0.810) \\
\end{array}$ & $3.094^{*}$ & $\begin{array}{c}4.28 \\
(0.807) \\
\end{array}$ & $\begin{array}{c}4.46 \\
(0.762) \\
\end{array}$ & -1.430 \\
\hline Cleanliness of the castle & $\begin{array}{c}4.71 \\
(0.554)\end{array}$ & $\begin{array}{c}4.60 \\
(0.613) \\
\end{array}$ & 1.208 & $\begin{array}{c}4.65 \\
(0.599) \\
\end{array}$ & $\begin{array}{c}4.70 \\
(0.537)\end{array}$ & -0.473 \\
\hline $\begin{array}{l}\text { Unique touch of weapons and } \\
\text { armors }\end{array}$ & $\begin{array}{c}4.62 \\
(0.702)\end{array}$ & $\begin{array}{c}4.50 \\
(0.741)\end{array}$ & 1.053 & $\begin{array}{c}4.50 \\
(0.789)\end{array}$ & $\begin{array}{c}4.73 \\
(0.522)\end{array}$ & $-2.302 * *$ \\
\hline Unique taste of local products & $\begin{array}{c}4.45 \\
(0.943) \\
\end{array}$ & $\begin{array}{c}4.19 \\
(0.926) \\
\end{array}$ & 1.657 & $\begin{array}{c}4.20 \\
(1.013)\end{array}$ & $\begin{array}{c}4.65 \\
(0.705) \\
\end{array}$ & $-3.253^{*}$ \\
\hline Local experience & $\begin{array}{c}4.65 \\
(0.684) \\
\end{array}$ & $\begin{array}{c}4.53 \\
(0.728) \\
\end{array}$ & 1.062 & $\begin{array}{c}4.58 \\
(0.730) \\
\end{array}$ & $\begin{array}{c}4.65 \\
(0.645) \\
\end{array}$ & -0.678 \\
\hline Castle's atmosphere & $\begin{array}{c}4.44 \\
(0.871)\end{array}$ & $\begin{array}{c}4.33 \\
(0.831) \\
\end{array}$ & 0.788 & $\begin{array}{c}4.42 \\
(0.763)\end{array}$ & $\begin{array}{c}4.36 \\
(1.017)\end{array}$ & 0.385 \\
\hline Fresh air inside the castle & $\begin{array}{c}4.76 \\
(0.511) \\
\end{array}$ & $\begin{array}{c}4.39 \\
(0.912) \\
\end{array}$ & $3.400^{*}$ & $\begin{array}{c}4.53 \\
(0.803) \\
\end{array}$ & $\begin{array}{c}4.80 \\
(0.444) \\
\end{array}$ & $-2.832 * *$ \\
\hline $\begin{array}{l}\text { Stimulating smell of castle's } \\
\text { traditional products }\end{array}$ & $\begin{array}{c}4.07 \\
(1.051)\end{array}$ & $\begin{array}{c}3.85 \\
(1.071) \\
\end{array}$ & 1.265 & $\begin{array}{c}3.90 \\
(1.041)\end{array}$ & $\begin{array}{c}4.16 \\
(1.085)\end{array}$ & -1.523 \\
\hline Smell of fire and weapons & $\begin{array}{c}4.73 \\
(0.528)\end{array}$ & $\begin{array}{c}4.63 \\
(0.633)\end{array}$ & 1.083 & $\begin{array}{c}4.64 \\
(0.601)\end{array}$ & $\begin{array}{c}4.79 \\
(0.494)\end{array}$ & -1.638 \\
\hline Pleasurable music in the castle & $\begin{array}{c}4.74 \\
(0.504)\end{array}$ & $\begin{array}{c}4.60 \\
(0.689) \\
\end{array}$ & 1.403 & $\begin{array}{c}4.65 \\
(0.614) \\
\end{array}$ & $\begin{array}{c}4.75 \\
(0.513) \\
\end{array}$ & -1.091 \\
\hline Sound of battles & $\begin{array}{c}4.77 \\
(0.528)\end{array}$ & $\begin{array}{c}4.69 \\
(0.561)\end{array}$ & 0.846 & $\begin{array}{c}4.68 \\
(0.591)\end{array}$ & $\begin{array}{c}4.86 \\
(0.401)\end{array}$ & $-2.285^{* *}$ \\
\hline
\end{tabular}




\begin{tabular}{|c|c|c|c|c|c|c|}
\hline \multirow{2}{*}{ Variables } & \multicolumn{3}{|c|}{ Tourist origin } & \multicolumn{3}{|c|}{ Number of visits } \\
\hline & Domestic & Foreign & T-value & First time & Repeated & T-value \\
\hline Sound of history & $\begin{array}{c}4.79 \\
(0.457)\end{array}$ & $\begin{array}{c}4.57 \\
(0.618)\end{array}$ & $2.336^{* *}$ & $\begin{array}{c}4.67 \\
(0.564)\end{array}$ & $\begin{array}{c}4.79 \\
(0.456)\end{array}$ & -1.460 \\
\hline $\begin{array}{l}\text { Matching music with the } \\
\text { atmosphere }\end{array}$ & $\begin{array}{c}4.76 \\
(0.551)\end{array}$ & $\begin{array}{c}4,60 \\
(0.586)\end{array}$ & 1.743 & $\begin{array}{c}4.66 \\
(0.597)\end{array}$ & $\begin{array}{c}4.77 \\
(0.504)\end{array}$ & -1.215 \\
\hline On-site engagement & 4.59 & 4.49 & & 4.49 & 4.67 & \\
\hline Interactive exhibitions & $\begin{array}{c}4.58 \\
(0.667)\end{array}$ & $\begin{array}{c}4.56 \\
(0.749)\end{array}$ & 0.217 & $\begin{array}{c}4.50 \\
(0.774)\end{array}$ & $\begin{array}{c}4.73 \\
(0.489)\end{array}$ & $-2.315^{* *}$ \\
\hline Educational games & $\begin{array}{c}4.49 \\
(0.782) \\
\end{array}$ & $\begin{array}{c}4.32 \\
(0.854) \\
\end{array}$ & 1.277 & $\begin{array}{c}4.37 \\
(0.865) \\
\end{array}$ & $\begin{array}{c}4.53 \\
(0.690) \\
\end{array}$ & -1.184 \\
\hline Special events & $\begin{array}{c}4.69 \\
(0.596)\end{array}$ & $\begin{array}{c}4.60 \\
(0.616)\end{array}$ & 0.946 & $\begin{array}{c}4.60 \\
(0.643)\end{array}$ & $\begin{array}{c}4.76 \\
(0.508)\end{array}$ & -1.725 \\
\hline Staff & 4.91 & 4.73 & & 4.80 & 4.93 & \\
\hline Friendly staff & $\begin{array}{c}4.94 \\
(0.235)\end{array}$ & $\begin{array}{c}4.89 \\
(0.321)\end{array}$ & 1.196 & $\begin{array}{c}4.89 \\
(0.316)\end{array}$ & $\begin{array}{c}4.98 \\
(0.134)\end{array}$ & $-2.646^{*}$ \\
\hline Knowledgeable staff & $\begin{array}{c}4.90 \\
(0.330)\end{array}$ & $\begin{array}{c}4.69 \\
(0.647)\end{array}$ & $2.398 * *$ & $\begin{array}{c}4.78 \\
(0.537)\end{array}$ & $\begin{array}{c}4.91 \\
(0.345)\end{array}$ & -1.943 \\
\hline Relevant information & $\begin{array}{c}4.83 \\
(0.422) \\
\end{array}$ & $\begin{array}{c}4.54 \\
(0.697) \\
\end{array}$ & $2.985^{*}$ & $\begin{array}{c}4.67 \\
(0.596) \\
\end{array}$ & $\begin{array}{c}4.84 \\
(0.458) \\
\end{array}$ & $-2.057 * *$ \\
\hline Helpful staff & $\begin{array}{c}4.96 \\
(0.194) \\
\end{array}$ & $\begin{array}{c}4.80 \\
(0.440) \\
\end{array}$ & $2.651^{*}$ & $\begin{array}{c}4.85 \\
(0.382) \\
\end{array}$ & $\begin{array}{c}5.00 \\
(0.000) \\
\end{array}$ & $-4.028^{*}$ \\
\hline Learning & 4.53 & 4.11 & & 4.26 & 4.59 & \\
\hline Learn a lot & $\begin{array}{c}4.53 \\
(0.752) \\
\end{array}$ & $\begin{array}{c}4.03 \\
(1.095)\end{array}$ & $3.161^{*}$ & $\begin{array}{c}4.22 \\
(1.035)\end{array}$ & $\begin{array}{c}4.59 \\
(0.596)\end{array}$ & $-2.878^{*}$ \\
\hline Learn new things & $\begin{array}{c}4.53 \\
(0.752)\end{array}$ & $\begin{array}{c}4.18 \\
(0.915)\end{array}$ & $2.588^{* *}$ & $\begin{array}{c}4.30 \\
(0.887)\end{array}$ & $\begin{array}{c}4.59 \\
(0.682)\end{array}$ & $-2.300 * *$ \\
\hline Emotions & 4.84 & 4.62 & & 4.71 & 4.86 & \\
\hline Pleasant visit & $\begin{array}{c}4.89 \\
(0.310)\end{array}$ & $\begin{array}{c}4.71 \\
(0.555)\end{array}$ & $2.389 * *$ & $\begin{array}{c}4.78 \\
(0.478)\end{array}$ & $\begin{array}{c}4.91 \\
(0.288)\end{array}$ & $-2.188 * *$ \\
\hline Exciting visit & $\begin{array}{c}4.81 \\
(0.486)\end{array}$ & $\begin{array}{c}4.60 \\
(0.689)\end{array}$ & $2.097 * *$ & $\begin{array}{c}4.66 \\
(0.656)\end{array}$ & $\begin{array}{c}4.86 \\
(0.353)\end{array}$ & $-2.503 * *$ \\
\hline Funny visit & $\begin{array}{c}40.83 \\
(0.373)\end{array}$ & $\begin{array}{c}4.56 \\
(0.617) \\
\end{array}$ & $3.123^{*}$ & $\begin{array}{c}4.69 \\
(0.522)\end{array}$ & $\begin{array}{c}4.82 \\
(0.431)\end{array}$ & -1.749 \\
\hline
\end{tabular}

Note: * significant at $0.01 ; *$ significant at 0.05 ; values in bold are overall mean scores for each dimension; values in parentheses are standard deviations

Source: Authors

As presented in Table 1, domestic visitors evaluated tourism experience elements with mean scores ranging from 4.07 to 4.96 . With the lowest score was rated the element "stimulating smell of castle's traditional products", while the highest score was given to the element "helpful staff". Similarly, foreign visitors' mean scores ranged from 3.85 (for the element "stimulating smell of castle's traditional products") to 4.89 (for the element "friendly staff"). Overall, both, domestic and foreign visitors expressed the highest rated experience regarding dimensions "staff" and "emotions". On the other hand, the least rated experience was connected with the dimension "learning".

When comparing experience scores between domestic and foreign visitors, the analysis indicated higher scores in the domestic visitors' sample for all 29 tourism experience elements. The results of the independent samples t-test revealed significant differences in 11 cases. Thus, domestic visitors reported significantly more positive experience than foreign visitors with the following tourism experience elements: "unique interior", "fresh air inside the castle", "sound of history", 
"knowledgeable staff", "relevant information", "helpful staff”, "learn a lot", "learn new things", "pleasant visit", "exciting visit", and "funny visit".

Furthermore, Table 1 compares tourism experience levels between first-time and repeated visitors, as well. First-time visitors evaluated tourism experience elements with mean scores ranging from 3.90 (for the element "stimulating smell of castle's traditional products") to 4.89 (for the element "friendly staff"). Likewise, repeated visitors' mean scores ranged from 4.16 (for the element "stimulating smell of castle's traditional products") to 5.00 (for the element "helpful staff"). Overall, both, first-time and repeated visitors expressed the highest rated experience concerning dimensions "staff" and "emotions", while the least rated experience considered dimension "learning".

The analysis of difference indicated higher scores in repeated visitors' sample for 28 tourism experience elements. Only for the element "castle's atmosphere" first-time visitors expressed higher tourism experience scores. However, the results show that for 12 elements identified differences were significant between these two groups of respondents. Thus, repeated visitors reported significantly more positive experience than first-time visitors with following tourism experience elements: "unique touch of the weapons and armors", "unique taste of local products", "fresh air inside the castle", "sound of battles", "interactive exhibitions", "friendly staff", "relevant information", "helpful staff", "learn a lot", "learn new things", "pleasant visit", and "exciting visit".

Table 2 reports the results of descriptive and bivariate statistical analyses for tourism experience outcomes scores.

Table 2. The comparison of tourism experience outcomes scores

\begin{tabular}{|l|l|l|l|l|l|l|}
\hline \multirow{2}{*}{ Variables } & \multicolumn{3}{|c|}{ Tourist origin } & \multicolumn{3}{c|}{ Number of visits } \\
\cline { 2 - 7 } & Domestic & \multicolumn{1}{|c|}{ Foreign } & T-value & First time & Repeated & T-value \\
\hline Satisfaction & 4.72 & 4.56 & & 4.58 & 4.80 & \\
\hline $\begin{array}{l}\text { I feel good about coming to } \\
\text { the castle for the offerings I'm } \\
\text { looking for. }\end{array}$ & $\begin{array}{l}4.61 \\
(0.581)\end{array}$ & $\begin{array}{l}4.53 \\
(0.620)\end{array}$ & 0.829 & $\begin{array}{l}4.51 \\
(0.633)\end{array}$ & $\begin{array}{l}4,71 \\
(0.494)\end{array}$ & $-2.237^{* *}$ \\
\hline $\begin{array}{l}\text { My feelings towards the castle } \\
\text { are very positive. }\end{array}$ & $\begin{array}{l}4.74 \\
(0.484)\end{array}$ & $\begin{array}{l}4.63 \\
(0.550)\end{array}$ & 1.286 & $\begin{array}{l}4.62 \\
(0.541)\end{array}$ & $\begin{array}{l}4.84 \\
(0.417)\end{array}$ & $-2.833^{*}$ \\
\hline $\begin{array}{l}\text { The extent to which the castle } \\
\text { has produced the best possible } \\
\text { outcome for me is satisfying. }\end{array}$ & $\begin{array}{l}4.71 \\
(0.517)\end{array}$ & $\begin{array}{l}4.45 \\
(0.739)\end{array}$ & $2.407^{* *}$ & $\begin{array}{l}4.53 \\
(0.688)\end{array}$ & $\begin{array}{l}4.77 \\
(0.426)\end{array}$ & $-2.707^{*}$ \\
\hline $\begin{array}{l}\text { Overall I'm satisfied with the } \\
\text { castle and the service they } \\
\text { provide. }\end{array}$ & $\begin{array}{l}4.82 \\
(0.437)\end{array}$ & $\begin{array}{l}4.61 \\
(0.556)\end{array}$ & $2.511^{* *}$ & $\begin{array}{l}4.66 \\
(0.532)\end{array}$ & $\begin{array}{l}4.89 \\
(0.366)\end{array}$ & $-3.326^{*}$ \\
\hline Behavioral intentions & 4.82 & 4.61 & & 4.66 & 4.92 & \\
\hline $\begin{array}{l}\text { I will recommend the castle to } \\
\text { other people. }\end{array}$ & $\begin{array}{l}4.90 \\
(0.357)\end{array}$ & $\begin{array}{l}4.75 \\
(0.505)\end{array}$ & $2.021^{* *}$ & $\begin{array}{l}4.80 \\
(0.488)\end{array}$ & $\begin{array}{l}4.95 \\
(0.227)\end{array}$ & $-2.683^{*}$ \\
\hline $\begin{array}{l}\text { I will say positive things about } \\
\text { the castle to other people. }\end{array}$ & $\begin{array}{l}4.88 \\
(0.378)\end{array}$ & $\begin{array}{l}4.82 \\
(0.426)\end{array}$ & 0.955 & $\begin{array}{l}4.81 \\
(0.461)\end{array}$ & $\begin{array}{l}4.96 \\
(0.187)\end{array}$ & $-3.092^{*}$ \\
\hline $\begin{array}{l}\text { I will encourage friends and } \\
\text { relatives to visit the castle. }\end{array}$ & $\begin{array}{l}4.85 \\
(0.429)\end{array}$ & $\begin{array}{l}4.68 \\
(0.536)\end{array}$ & $2.207^{* *}$ & $\begin{array}{l}4.72 \\
(0.546)\end{array}$ & $\begin{array}{l}4.93 \\
(0.260)\end{array}$ & $-3.393^{*}$ \\
\hline $\begin{array}{l}\text { I will revisit the castle in the } \\
\text { future. }\end{array}$ & $\begin{array}{l}4.65 \\
(0.724)\end{array}$ & $\begin{array}{l}4.17 \\
(1.044)\end{array}$ & $3.172^{*}$ & $\begin{array}{l}4.29 \\
(0.971)\end{array}$ & $\begin{array}{l}4.82 \\
(0.543)\end{array}$ & $-4.481^{*}$ \\
\hline Memory & 4.74 & 4.50 & & 4.56 & 4.81 & \\
\hline $\begin{array}{l}\text { I have wonderful memories of } \\
\text { experiences in the castle. }\end{array}$ & $\begin{array}{l}4.74 \\
(0.504)\end{array}$ & $\begin{array}{l}4.47 \\
(0.762)\end{array}$ & $2.483^{* *}$ & $\begin{array}{l}4.55 \\
(0.687)\end{array}$ & $\begin{array}{l}4.80 \\
(0.444)\end{array}$ & $-2.8571^{*}$ \\
\hline
\end{tabular}




\begin{tabular}{|l|l|l|l|l|l|l|}
\hline \multirow{2}{*}{ Variables } & \multicolumn{3}{|c|}{ Tourist origin } & \multicolumn{3}{c|}{ Number of visits } \\
\cline { 2 - 7 } & Domestic & Foreign & T-value & First time & Repeated & T-value \\
\hline $\begin{array}{l}\text { I won't forget my experiences } \\
\text { in the castle. }\end{array}$ & $\begin{array}{l}4.74 \\
(0.542)\end{array}$ & $\begin{array}{l}4.46 \\
(0.828)\end{array}$ & $2.349 * *$ & $\begin{array}{l}4.54 \\
(0.754)\end{array}$ & $\begin{array}{l}4.82 \\
(0.431)\end{array}$ & $-3.070^{*}$ \\
\hline $\begin{array}{l}\text { I will remember my } \\
\text { experiences in the castle. }\end{array}$ & $\begin{array}{l}4.74 \\
(0.559)\end{array}$ & $\begin{array}{l}4.57 \\
(0.694)\end{array}$ & 1.569 & $\begin{array}{l}4.60 \\
(0.683)\end{array}$ & $\begin{array}{l}4.82 \\
(0.431)\end{array}$ & $-2.513^{* *}$ \\
\hline
\end{tabular}

Note: $*$ significant at $0.01 ; * *$ significant at 0.05 ; values in bold are overall mean scores for each dimension; values in parentheses are standard deviations

Source: Authors

As presented in Table 2, satisfaction scores for domestic visitors were very high and ranged from 4.61 to 4.82 , while for foreign visitors were slightly lower, ranging from 4.45 to 4.63 . Overall, domestic visitors were highly satisfied with their tourism experience, while foreign visitors expressed a fairly level of satisfaction. Comparison of satisfaction scores between domestic and foreign visitors revealed higher scores for the domestic sample. Besides, significant differences occurred in 2 out of 4 variables. Hence, domestic visitors were significantly more satisfied than foreign ones.

In addition, satisfaction scores for first-time visitors ranged between 4.51 and 4.66, while for repeated visitors were higher, ranging between 4.71 and 4.89. Overall, first-time visitors reported a fairly level of satisfaction, while repeated visitors were highly satisfied with their tourism experience. Comparison of satisfaction scores between first-time and repeated visitors revealed significantly higher scores in all variables for repeated visitors, meaning that they were significantly more satisfied than first-time visitors.

Behavioral intentions scores for domestic visitors varied between 4.65 and 4.90, while for foreign visitors were slightly lower, varying from 4.17 to 4.82 . Overall, both groups of visitors expressed positive behavioral intentions. Comparison of behavioral intentions scores between domestic and foreign visitors revealed higher scores for the domestic sample. Besides, significant differences were found in most of the variables, indicating that domestic visitors are significantly more likely to spread positive word of mouth, and are more likely to revisit the site.

Additionally, behavioral intentions scores for first-time and repeated visitors varied from 4.29 to 4.81, and from 4.82 to 4.96, respectively. Overall, both groups of visitors expressed positive behavioral intentions. Comparison of behavioral intentions scores between first-time and repeated visitors revealed significantly higher scores in all variables for repeated visitors, indicating that they expressed more positive behavioral intentions than first-time visitors.

In relation to the memory, domestic visitors evaluated all variables equally, with a mean score of 4.74, while scores for foreign visitors varied between 4.46 and 4.57. Overall, both groups of visitors expressed positive memory. Comparison of memory scores between domestic and foreign visitors revealed higher scores for the domestic sample. Besides, significant differences were found in most of the variables, indicating that domestic visitors created more positive and memorable memories.

Finally, memory scores for first-time visitors varied from 4.54 to 4.60 , and for repeated visitors were much higher, between 4.80 and 4.82 . Overall, both groups of visitors expressed positive memory. Comparison of memory scores between first-time and repeated visitors revealed significantly higher scores in all variables for repeated visitors, indicating that they created more positive, unforgettable memories than first-time visitors. 


\section{CONCLUSION}

The present study examined tourism experience dimensions and outcomes from the perspective of different tourists segments. Specifically, the aim was to identify potential differences between domestic and foreign visitors, as well as between first-time and repeated visitors regarding their heritage tourism experience.

In order to answer research questions, the study was conducted from a conceptual and empirical point of view. Firstly, the results of the conceptual analysis suggested that tourism experience is a multidimensional construct that comprises both tangible and intangible elements (dimensions), leading to different tourism experience outcomes (e.g. satisfaction, loyalty, memories).

Secondly, the results of the empirical part of the study revealed that visitors experienced local heritage site very positively. Among that, staff and emotions were the best-perceived tourism experience elements. Additionally, considering tourism experience outcomes, heritage visitors expressed high levels of satisfaction, as well as positive behavioral intentions and memory.

Thirdly, in the context of the present paper, the assumption was that visitors' characteristics, in terms of nationality and number of visits, influence visitors' experience in heritage tourism. The study results identified that nationality influences heritage visitors' experience. This is in line with the findings of Sayan \& Karagüzel (2010), and Prayag \& Ryan (2011).

Domestic visitors reported significantly more positive experiences regarding staff, learning, and emotions at the local heritage site. What is more, they were significantly more satisfied, they were more likely to spread positive word of mouth and revisit the site, as well as they, were more likely to have a highly memorable heritage site experience than foreigners. Moreover, the results confirm that first-time and repeated visitors experience the destination in different ways (McKercher et al., 2011). Repeated visitors expressed significantly more positive experience toward staff, learning and emotions considering local heritage site. In addition, repeaters were significantly more satisfied, they expressed more positive behavioral intentions, and they created more positive, unforgettable memories than first-time visitors.

The study results generate practical and academic implications in the heritage tourism experience context. They indicate tourism experience elements that are well recognized (e.g. staff, emotions, senses), as well as the ones that could be improved (e.g. learning). In addition, results demonstrate that nationality and number of visits have an important role in creating visitors' experiences at the local heritage site. Thus, these visitors' characteristics should also be considered when trying to understand heritage visitors' behavioral patterns and perceptions in terms of experiencing heritage site. These results can help heritage site managers to create an excellent tourism experience tailored to specific tourists segments.

There are limitations relating to the present study. Although the sample comprises the population's characteristics, it should be broadened for conducting more complex analyses. Also, since data was gathered during the COVID-19 pandemic, this could influence visitors' structure and affect the sample structure. While this study discusses the role of nationality and number of visits in creating visitors' experience, other demographic and visit-related characteristics should be taken into consideration, as well. These characteristics can include gender, age, motivations, previous experience at similar sites. Future research could address these issues, as well as examine how different tourism experience dimensions affect tourism experience outcomes. 


\section{REFERENCES}

Agapito, D., Mendes, J., \& Valle, P. (2013). Exploring the conceptualization of sensory dimension of tourist experiences. Journal of Destination Marketing \& Management 2, 62 -73. http:// dx.doi.org/10.1016/j.jdmm.2013.03.001

Ali, F., Hussain, K., Ragavan, N. A. (2014). Memorable customer experience: examining the effects of customers experience on memories and loyalty in Malaysian resort hotels. Procedia - Social and Behavioral Sciences, 144, 273 - 279.

Anil, N. (2012). Festival visitors' satisfaction and loyalty: An example of small, local, and municipality organized festival. Tourism, 60(3), $255-271$.

Chandralal, L., \& Valenzuela, F. (2015). Memorable Tourism Experiences: Scale Development. Contemporary Management Research, 11(3), 291 - 310. https://doi.org/10.7903/cmr.13822

Chen, H., \& Rahman, I. (2018). Cultural tourism: An analysis of engagement, cultural contact, memorable tourism experience and destination loyalty. Tourism Management Perspectives, 26, 153-163.

Chua, B. L., Kim, H. C., Lee, S., \& Han, H. (2019). The role of brand personality, self-congruity, and sensory experience in elucidating sky lounge users' behavior. Journal of Travel \& Tourism Marketing, 36(1), 29 -42. https://doi.org/10.1080/10548408.2018.1488650

Dagger, T., Sweeney, J., \& Johnson, L. (2007). A hierarchical model of health service quality: scale development and investigation of an integrated model. Journal of Service Research 10(2), 123 - 142. https://doi.org/10.1177/1094670507309594

Godovykh, M., \& Tasci A. D. A. (2020). Customer experience in tourism: A review of definitions, components, and measurements. Tourism Management Perspectives, 35. https://doi. org/10.1016/j.tmp.2020.100694

Joyner, L., Kline, C., Oliver, J., \& Kariko, D. (2018). Exploring emotional response to images used in agritourism destination marketing. Journal of Destination Marketing \& Management, 9 , 44-55. https://doi.org/10.1016/j.jdmm.2017.10.004

Kempiak, J., Hollywood, L., Bolan, P., \& McMahon-Beattie, U. (2017). The heritage tourist: an understanding of the visitor experience at heritage attractions. International Journal of Heritage Studies, 23(4), 375-392. http://dx.doi.org/10.1080/13527258.2016.1277776

Kim, D., \& Perdue, R. (2013). The Effect of Cognitive, Affective, and Sensory Attributes on Hotel Choice. International Journal of Hospitality Management, 35, 246 - 257. https://doi. org/10.1016/j.ijhm.2013.05.012

Marković, S., Dorčić, J., \& Krnetić, M. (2015). Visitor satisfaction and loyalty measurement of a local food festival: Application of FESTPERF scale. International Scientific Conference Tourism in Southern and Eastern Europe ToSEE, 3, 183 - 196.

McKercher, B., Shoval, N., Ng, E., \& Birenboim, A. (2011). First and Repeat Visitor Behaviour: GPS Tracking and GIS Analysis in Hong Kong. Tourism Geographies, 1-15. http://dx.doi.or $\mathrm{g} / 10.1080 / 14616688.2011 .598542$

Oh, H., Fiore, A. M., \& Jeoung, M. (2007). Measuring Experience Economy Concepts: Tourism Applications. Journal of Travel Research, 46(November), 119-132. http://dx.doi. org/10.1177/0047287507304039

Packer, J., \& Ballantyne, R. (2016). Conceptualizing the visitor experience: A review of literature and development of a multifaceted model. Visitor Studies, 19(2), 128-143.

Pine, B. J., \& Gilmore, J. H. (1998). Welcome to the experience economy. Harvard Business Review, (July-August), 97-105.

Prayag, G., \& Ryan, C. (2011). The relationship between the 'push' and 'pull' factors of a tourist destination: the role of nationality - an analytical qualitative research approach. Current Issues in Tourism, 14(2), 121-143. http://dx.doi.org/10.1080/13683501003623802 
Sayan, S., \& Karagüzel, O. (2010). Problems of Outdoor Recreation: The Effect of Visitors' Demographics on the Perceptions of Termessos National Park, Turkey. Environmental Management, 45, 1257-1270. http://dx.doi.org/10.1007/s00267-010-9500-8

Schmitt, B. (1999). Experiential marketing. Journal of Marketing Management, 15(1-3), 53-67. https://doi.org/10.1362/026725799784870496

Seyfi, S., Hall, C. M., \& Rasoolimanesh, S. M. (2019). Exploring memorable cultural tourism experiences. Journal of Heritage Tourism. https://doi.org/10.1080/1743873X.2019.1639717

Schmitt, B. (1999). Experiential marketing. Journal of Marketing Management, 15(1-3), 53-67. https://doi.org/10.1362/026725799784870496

Suhartanto, D., Dean, D., Chen, B. T., \& Kusdibyo, L. (2020). Tourist experience with agritourism attractions: what leads to loyalty? Tourism Recreation Research. https://doi.org/10.1080/02 508281.2020 .1736251

Ung, A., \& Vong, T. N. (2010). Tourist experience of heritage tourism in Macau SAR, China. Journal of Heritage Tourism, 5(2), 157 - 168. http://dx.doi.org/10.1080/17438731003668502

Zeithamal, V. A., Berry, L. L., \& Parasuraman, A. (1996). The behavioral consequences of service quality. The Journal of Marketing, 60(2), 31 - 46. https://doi.org/10.2307/1251929 